\title{
Research on the Leader Motivation of Manufacturing Enterprises--a Case Study of Haier in Wuhan ${ }^{1}$
}

\author{
You-Jun WU ${ }^{1, a,{ }^{,}, \text {Li-Juan ZHAO }}{ }^{2, b}$, Shao-Wei YANG $^{3, c}$, Xiong-Min DAl ${ }^{4, d}$ and \\ Meng $\mathrm{Xu}^{5, \mathrm{e}}$ \\ ${ }^{1}$ College of Management, Wuhan university of science and technology, wuhan city, China. \\ ${ }^{2}$ College of Management, Wuhan university of science and technology, wuhan city, China. \\ ${ }^{3}$ College of Management, Wuhan university of science and technology, wuhan city, China. \\ ${ }^{4}$ College of Management, Wuhan university of science and technology, wuhan city, China. \\ ${ }^{5}$ College of Management, Wuhan university of science and technology, wuhan city, China. \\ a656152185@qq.com, $1250342458 @ q q . c o m,{ }^{c} 670098973 @ q q . c o m,{ }^{d} 1960686826 @ q q . c o m,{ }^{e} 139$ \\ 5195467@qq.com \\ ${ }^{*}$ Corresponding author: You-jun WU
}

Key words: Manufacturing enterprises, Motivation, Monitor, Wuhan Haier

\begin{abstract}
With the advent of the Internet era, the ever-changing information technology, the manufacturing industry, as China's national economic base and pillar of , under the changes in the environment will have a certain impact, manufacturing enterprises must change the traditional concept, make use of favorable conditions and resources to comply with the times development. Based on manufacturing enterprises monitors' incentive perspective and the incentive theory related to the subject of this paper, this paper investigates and analyzes the present monitor encouragement situation of Wuhan Haier Electric Appliance Co., Ltd. (hereinafter referred to as Wuhan Haier) by the questionnaire survey method, and uses descriptive analysis to analyze the content of questionnaires and existing problems of the incentive mechanism of Wuhan Haier, and puts forward the measures to improve the monitor incentive mechanism of Wuhan Haier. Finally, concluded to reflect on research, described the future Outlook.
\end{abstract}

\section{Introduction}

In the context of the country's" Made in China 2025” proposed, China's manufacturing industry is still the mainstay of China's economy, both in the present and the visible 21st century. But the undeniable point is that in the last 10 years, China's internet economy, especially the bat-represented mobile internet economy, has had a huge impact on many Chinese industries, including manufacturing. The new era of digital design, analysis and manufacture requires the manufacturing enterprises to adopt the advanced manufacturing production mode and change the strategy to adapt to the development of modern economy and society. After China's successful entry into the World Trade Organization in 2001, China's economy ushered in a 10-year take-off, but the opportunities behind the opportunity also contains a huge challenge to domestic enterprises. Manufacturing enterprises are characterized by large organization structure and many employees. With the rising cost of human resources in recent years, the manufacturing industry's meager profits have been squeezed again, many manufacturing enterprises are struggling, and even forced layoffs. So the two key problems of the manufacturing industry are intelligent manufacturing to reduce

Fund Project: This is stage research results of Key projects in the humanities and social sciences of the Hubei Provincial Education Department ( 2017), which name is research on Innovation performance of enterprise R\& D personnel based on mental model(No.17D015) . 
production costs and improve staff efficiency to reduce the overall human cost.

For any enterprise, Enterprise's development inseparable from the first factor is the human factor. Similarly, relative to the manufacturing sector, only serious and sufficient to formulate a scientific staff incentive strategy, in order to maximize the mobilization of staff enthusiasm and creativity in the work to lead the organization hundred years Evergreen, so that enterprises always stand in the highest point of fierce competition. It has become one of the most concerned problems for manufacturing enterprises and their leaders to arouse employees ' enthusiasm and improve their individual performance level and overall performance level. To solve the problem of the motivation of the monitor not only has a direct positive impact on the efficiency of the monitor itself, but more importantly, it can promote all the front-line employees under the supervision of the monitor to effectively improve the behavior and improve the working efficiency.

The purpose of this paper is to find out the existing problems and propose corresponding solutions by investigating and analyzing the status quo of the incentive mechanism of the monitor in Wuhan, in order to induce the monitor's working motive correctly. On the one hand, we can achieve the goal by accomplishing the organization task successfully. Not only to enhance the staff's enthusiasm for work, creativity in the work, improve the personal performance of employees, but also for the improvement of the overall performance of the enterprise has a huge role in promoting. On the other hand, good staff incentive mechanism for the company's talent recruitment mechanism, recruitment effect has irreplaceable function, only the incentive effect is clear enough, effective enough to help companies attract outstanding talent, to help the company retain outstanding talent.

\section{Wuhan Haier Questionnaire Survey and Result Analysis}

\section{Company Profile}

Qingdao Haier Group in March 2002 invested in the establishment of Wuhan Haier Electric Co., Ltd., and well-known Haier Group is the world's first brand of white household appliances manufacturers, in air-conditioning, water heaters, refrigerators and other production and sales areas occupy a dominant position. In addition, Wuhan Haier also established the Wuhan HMS Center, HMS Center is not only the logistics center of Wuhan Haier, but also the marketing center. Therefore, the Wuhan Haier Group in the local market play a demand creation center, to meet the role of the center, but also Haier Group in Wuhan to achieve localized production sales and service base.

Wuhan Haier mainly includes air-conditioning, water heaters, refrigerators three production major departments. Air Conditioning Production department has a total of 4 production lines, and the water heater department has 5 production lines. The refrigerator, like the air-conditioning department, has 4 production lines. The official staff reached more than 1300 people.

\section{Research Samples}

The research object is 59 monitors of four production lines in Wuhan Haier air conditioning production department. The final study sample was 45 monitors.

Wuhan Haier air-conditioning production department monitor is mainly male, the number of 37 people, the sample percentage is up to $82.22 \%$.

Monitor team relatively younger, mainly distributed in the 21-30 age, the proportion of up to $60 \%$. Among them, 21 were men aged 21 - 30 and 6 were slaves aged $21-30$.

The findings of the academic level show that in all of the monitor, mainly to the major of the high school education, including 20 of male and 5 women under high school education, compared with 17 men and 3 women in the specialist category. There is no bachelor 's degree, master 's degree or above in all monitor classes, which indicates that there is no special requirement for the level of monitor.

Most of the monitor in Wuhan Haier work for 3-5 years, the second 1-2 years, very few working time is particularly short and 10 years long. And, there is a monitor under the age of 20, his working life is 1 - 2 years; Twenty - seven monitors, aged 21 - 30, have 15 working years of 3 - 5 years; 
There are 14 monitors aged 31 - 40 years, 7 of whom work for 3 - 5 years and 4 for 6 - 10 years; The three monitors, aged 41 - 50, have a working life of more than 10 years and 6 - 10 years. It is not difficult to see that the monitor in Wuhan Haier's working life is roughly correlated with his/her personal age.

To the monitor annual salary survey, the annual salary mainly concentrated in 450,000 and 40,000 , the annual salary of 570,000 of the monitor has 2 work 6-10 years, 2 work for more than 10 years, men's and women's annual salary is roughly equal.

\section{Design and Distribution of Questionnaires}

\section{The Design of the Questionnaire}

This research questionnaire is based on the maturity scale used by domestic and foreign scholars in empirical research, and is designed according to the actual situation of Wuhan Haier.

The first part of the basic personal Information survey, including gender, age, education, in Wuhan Haier working life, annual salary and so on.

The second part is the monitor of the current corporate incentive satisfaction survey, this paper relies on Oldever's "Erg Theory" and Hertz's "two-factor Need theory" to construct the self-compiling scale, and combine with Wuhan Haier to adjust the scale properly, including the needs of survival, growth and relationship need three dimensions. Using Likert Five points scoring mode, positive scoring, from very dissatisfied to very satisfied with 1-6 points respectively.

The third part is the importance of 13 options in the three dimensions mentioned above. Positive scoring, from unimportant to very important respectively, given 1-6 points.

\section{Distribution of Questionnaires}

The questionnaire was distributed in paper form on may 5, 2017 to 59 monitor of Wuhan Haier air conditioning production department, issued a total of 50 questionnaires, 47 recovery, recovery of $94 \%$, of which out of two invalid questionnaires after the effective questionnaire 45, effective rate of $95.7 \%$. Detailed data are shown in table 1.

\section{Questionnaire Contents and findings}

\section{Company Incentives Satisfaction Survey}

This part is the second part of the questionnaire, mainly from 13 incentive options to monitor the squad leader, the first seven options are from the perspective of survival needs, the middle four options are from the perspective of growth needs investigation, the latter two options can be summarized need for the relationship point of view. The survey results are shown in Table 1: 
Table1: Company Incentives Satisfaction Questionnaire

\begin{tabular}{|c|c|c|c|c|c|c|c|c|}
\hline \multicolumn{2}{|l|}{ Incentive options } & \multirow{2}{*}{$\begin{array}{c}\text { Very } \\
\text { dissatisfied } \\
\\
-\end{array}$} & \multirow{2}{*}{$\begin{array}{c}\text { Not } \\
\text { satisfied } \\
\\
\\
5\end{array}$} & \multirow{2}{*}{$\begin{array}{c}\text { General } \\
\\
15\end{array}$} & \multirow{2}{*}{$\begin{array}{c}\text { Satisfied } \\
\\
21\end{array}$} & \multirow{2}{*}{$\begin{array}{c}\text { very } \\
\text { satisfied } \\
\\
4\end{array}$} & \multirow{2}{*}{$\begin{array}{c}\text { The } \\
\text { average } \\
\text { score }\end{array}$} & \multirow{2}{*}{$\begin{array}{c}\begin{array}{c}\text { Standard } \\
\text { deviation }\end{array} \\
0.81\end{array}$} \\
\hline $\begin{array}{l}\text { The company's pay structure } \\
\text { (Whether the remuneration } \\
\text { component is reasonable) }\end{array}$ & $\begin{array}{l}\text { Number } \\
\text { of } \\
\text { people }\end{array}$ & & & & & & & \\
\hline $\begin{array}{l}\text { Where the basic salary } \\
\text { (The basic component of the } \\
\text { salary earned) }\end{array}$ & $\begin{array}{l}\text { Number } \\
\text { of } \\
\text { people }\end{array}$ & 6 & 17 & 16 & 5 & 1 & 2.51 & 0.93 \\
\hline $\begin{array}{c}\text { Performance pay } \\
\text { (Part of the salary linked to } \\
\text { the performance appraisal } \\
\text { result) }\end{array}$ & $\begin{array}{l}\text { Number } \\
\text { of } \\
\text { people }\end{array}$ & 5 & 19 & 13 & 7 & 1 & 2.56 & 0.96 \\
\hline $\begin{array}{l}\text { Company Bonuses, Welfare } \\
\text { Salary System (Whether the } \\
\text { Company's Bonuses, } \\
\text { Welfare Forms Are Various } \\
\text { and Effectively } \\
\text { Implemented) }\end{array}$ & $\begin{array}{l}\text { Number } \\
\text { of } \\
\text { people }\end{array}$ & 2 & 7 & 21 & 13 & 2 & 3.13 & 0.88 \\
\hline $\begin{array}{l}\text { Company flexible working } \\
\text { system of welfare (fixed } \\
\text { length of work hours can be } \\
\text { flexible arrangements for } \\
\text { working hours) }\end{array}$ & $\begin{array}{l}\text { Number } \\
\text { of } \\
\text { people }\end{array}$ & 1 & 22 & 18 & 4 & - & 2.56 & 0.68 \\
\hline $\begin{array}{l}\text { Benefits of company paid } \\
\text { leave }\end{array}$ & $\begin{array}{l}\text { Number } \\
\text { of } \\
\text { people }\end{array}$ & 2 & 13 & 16 & 10 & 4 & 3.02 & 1.02 \\
\hline $\begin{array}{l}\text { Working conditions and } \\
\text { working environment }\end{array}$ & $\begin{array}{c}\text { Number } \\
\text { of } \\
\text { people }\end{array}$ & - & - & 7 & 30 & 8 & 4.02 & 0.58 \\
\hline $\begin{array}{l}\text { A sense of achievement as a } \\
\text { result of the job }\end{array}$ & $\begin{array}{l}\text { Number } \\
\text { of } \\
\text { people }\end{array}$ & 2 & 9 & 26 & 7 & 1 & 2.91 & 0.78 \\
\hline $\begin{array}{l}\text { Promotion mechanism and } \\
\text { access } \\
\text { (With or without space for } \\
\text { job development) }\end{array}$ & $\begin{array}{l}\text { Number } \\
\text { of } \\
\text { people }\end{array}$ & 1 & 12 & 17 & 15 & - & 3.02 & 0.83 \\
\hline $\begin{array}{l}\text { Company training and } \\
\text { learning opportunities }\end{array}$ & $\begin{array}{l}\text { Number } \\
\text { of } \\
\text { people }\end{array}$ & 1 & 16 & 18 & 10 & - & 2.82 & 0.80 \\
\hline $\begin{array}{l}\text { Participate in management } \\
\text { decision-making }\end{array}$ & $\begin{array}{c}\text { Number } \\
\text { of } \\
\text { people }\end{array}$ & 10 & 27 & 8 & - & - & 1.96 & 0.63 \\
\hline $\begin{array}{l}\text { Relationship } \\
\text { (With the level, colleagues) }\end{array}$ & $\begin{array}{l}\text { Number } \\
\text { of } \\
\text { people }\end{array}$ & 4 & 8 & 20 & 13 & - & 2.93 & 0.90 \\
\hline company culture & $\begin{array}{l}\text { Number } \\
\text { of } \\
\text { people }\end{array}$ & - & 4 & 20 & 10 & 11 & 3.62 & 0.95 \\
\hline total people & & & & & eople & & & \\
\hline
\end{tabular}




\section{Investigation of Important Degree of Incentive Methods}

This part is the third part of the questionnaire, mainly from 13 incentive options to investigate the monitor, the first 7 options from the survival point of view, the middle 4 options from the perspective of growth needs, the latter 2 options can be summed up as a relationship needs angle. The results of the survey are shown in Table 2:

Table2: Importance extent list of incentive methods

\begin{tabular}{|c|c|c|c|c|c|c|c|c|}
\hline \multicolumn{2}{|c|}{ Incentive } & \multirow{2}{*}{$\begin{array}{c}\text { Not } \\
\text { important } \\
\end{array}$} & \multirow{2}{*}{$\begin{array}{c}\text { Not so } \\
\text { important } \\
\end{array}$} & \multirow{2}{*}{$\begin{array}{c}\text { Medium } \\
3\end{array}$} & \multirow{2}{*}{$\begin{array}{c}\begin{array}{c}\text { Quite } \\
\text { important }\end{array} \\
15\end{array}$} & \multirow{2}{*}{$\begin{array}{c}\begin{array}{c}\text { Very } \\
\text { important }\end{array} \\
27\end{array}$} & \multirow{2}{*}{$\begin{array}{c}\begin{array}{c}\text { Average } \\
\text { score }\end{array} \\
\\
4.53\end{array}$} & \multirow{2}{*}{$\begin{array}{r}\begin{array}{r}\text { Standard } \\
\text { deviation }\end{array} \\
0.62\end{array}$} \\
\hline $\begin{array}{c}\text { Reasonable and } \\
\text { complete } \\
\text { compensation } \\
\text { structure } \\
\end{array}$ & $\begin{array}{c}\text { Number } \\
\text { of } \\
\text { people }\end{array}$ & & & & & & & \\
\hline $\begin{array}{c}\text { Competitive basic } \\
\text { pay }\end{array}$ & $\begin{array}{c}\text { Number } \\
\text { of } \\
\text { people }\end{array}$ & - & - & 3 & 13 & 29 & 4.58 & 0.61 \\
\hline $\begin{array}{c}\text { Satisfying } \\
\text { performance pay }\end{array}$ & $\begin{array}{c}\text { Number } \\
\text { of } \\
\text { people }\end{array}$ & - & - & - & 14 & 31 & 4.69 & 0.46 \\
\hline $\begin{array}{l}\text { Various bonus } \\
\text { forms meeting } \\
\text { different } \\
\text { employees’ } \\
\text { demands and its } \\
\text { being effectively } \\
\text { carried out }\end{array}$ & $\begin{array}{c}\text { Number } \\
\text { of } \\
\text { people }\end{array}$ & - & - & 11 & 13 & 21 & 4.22 & 0.81 \\
\hline $\begin{array}{l}\text { Bonus of flexible } \\
\text { working system }\end{array}$ & $\begin{array}{c}\text { Number } \\
\text { of } \\
\text { people }\end{array}$ & 2 & 7 & 17 & 12 & 7 & 3.33 & 1.05 \\
\hline $\begin{array}{l}\text { Bonus of paid } \\
\text { holidays }\end{array}$ & $\begin{array}{c}\text { Number } \\
\text { of } \\
\text { people }\end{array}$ & - & 2 & 20 & 12 & 11 & 3.71 & 0.88 \\
\hline $\begin{array}{c}\text { Good work } \\
\text { condition and } \\
\text { environment }\end{array}$ & $\begin{array}{c}\text { Number } \\
\text { of } \\
\text { people }\end{array}$ & - & 1 & 14 & 19 & 11 & 3.88 & 0.80 \\
\hline $\begin{array}{c}\text { Work gives a } \\
\text { sense of } \\
\text { achievement }\end{array}$ & $\begin{array}{c}\text { Number } \\
\text { of } \\
\text { people }\end{array}$ & - & 2 & 16 & 12 & 15 & 3.89 & 0.92 \\
\hline $\begin{array}{c}\text { Complete } \\
\text { promotion } \\
\text { institution and } \\
\text { channels }\end{array}$ & $\begin{array}{c}\text { Number } \\
\text { of } \\
\text { people }\end{array}$ & - & 2 & 3 & 10 & 30 & 4.51 & 0.81 \\
\hline $\begin{array}{l}\text { Complete training } \\
\text { system with } \\
\text { many training } \\
\text { and study } \\
\text { opportunities } \\
\end{array}$ & $\begin{array}{c}\text { Number } \\
\text { of } \\
\text { people }\end{array}$ & 1 & 1 & 14 & 16 & 13 & 3.87 & 0.93 \\
\hline $\begin{array}{c}\text { Having } \\
\text { opportunities of } \\
\text { participating } \\
\text { company's } \\
\text { management } \\
\text { decision } \\
\end{array}$ & $\begin{array}{c}\text { Number } \\
\text { of } \\
\text { people }\end{array}$ & - & 1 & 11 & 18 & 15 & 4.04 & 0.82 \\
\hline $\begin{array}{c}\text { harmonious } \\
\text { relationship(with } \\
\text { colleagues) }\end{array}$ & $\begin{array}{c}\text { Number } \\
\text { of } \\
\text { people }\end{array}$ & - & 3 & 13 & 20 & 9 & 3.78 & 0.84 \\
\hline $\begin{array}{l}\text { Good corporate } \\
\text { culture }\end{array}$ & $\begin{array}{c}\text { Number } \\
\text { of } \\
\text { people }\end{array}$ & - & 3 & 16 & 17 & 9 & 3.71 & 0.86 \\
\hline Total number of & eople & & & & 45 & & & \\
\hline
\end{tabular}


This part of the survey through the monitor of each incentive option to the importance of the number and importance of the value assigned to the score to find scores, average points and standard deviation. Similarly, this part of the survey set the average score of 1 points to the lowest level, between 1-2 points for a very low degree of importance, 2-3 points between the importance is relatively low, 3 points to the median, 3-4 points between the importance is higher, 4-5 points between the importance is very high, 5 points the highest.

According to table 2 can be obtained, monitor agree with the important degree of the above incentive options, in which all the average scores were above 3, and the "reasonable compensation structure", "competitive basic salary", "satisfactory performance salary and bonus and welfare implementation of four with an average score of 4 points above, reflects the incentive effect of income is the biggest to monitor. Secondly, monitor pays much attention to their own development. It is very important for the company to have good promotion mechanism and perfect promotion channel. Therefore, the company should focus on the development of employees. The monitor also thinks that it is very important to participate in the management and decision-making of the company. Up to $73.33 \%$ of the monitor agree with the importance of having the opportunity to participate in the management and decision-making of the company.

In the "flexible working system", the monitor thinks that the welfare of the flexible working system is more important. Especially for the female employees, there are 6 female monitors in 8 people who hold a more important and important view of flexible work system, accounting for $75 \%$. Compared with the men, the demand is stronger. The standard deviation is the largest, indicating that the results of the investigation are very discrete. The detailed data are shown in Chart 1:

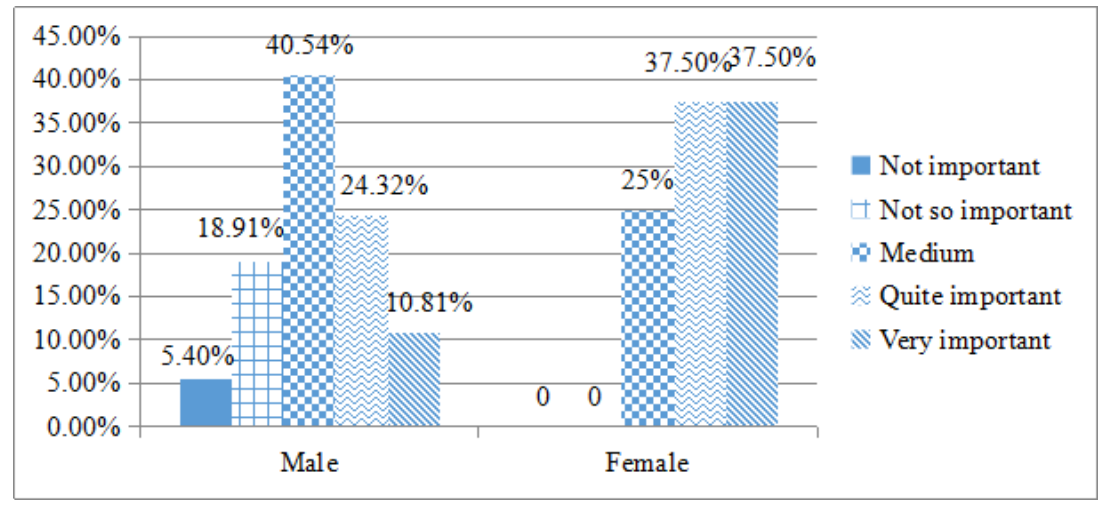

Chart 1. "Bonus of flexible working system” investigation chart

Several factors such as paid vacation, working conditions, whether work content brings sense of achievement, training and learning opportunities, interpersonal relationship and good corporate culture are important for monitor's incentive effect.

\section{Suggestions of Improving The Monitor Incentive Mechanism of Wuhan Haier}

\section{Incentives Based on the Needs of Survival}

The company should formulate a reasonable salary system and welfare policy. The general salary of the monitor is not high, the demand for material reward is strong, and the higher labor remuneration can improve the active initiative of the work. At present, the company implements piecework wage system. The company can raise the single piece wage appropriately, and give bonus to the monitor who completes the production line with high efficiency and high product qualification rate. At the same time, it is necessary to consider the internal equity, and the same as the monitor, the wage gap may make the employee psychological imbalance, not conducive to the effect of incentive. Therefore, the wage and working life, education, production line labor intensity and production line product completion rate, product loss rate and so on, will give employees a fair and reasonable feeling. 


\section{Incentives Based on Growth Needs}

\section{Production Line Rotation}

In general, most monitor will continue for a long time in a production line, work long single the employees will gradually produce burnout, employees spend freshness and enthusiasm, repetitive work will make employees feel the lack of challenging work content and did not have a sense of achievement. There are four production lines in the air conditioning workshop, and the 22 parts are responsible for the production of the indoor and outdoor machines. Therefore, it is possible to regularly organize work rotation between the indoor and outdoor machine production lines.Besides, there are 5 production lines in the workshop of Wuhan Haier electric water heater production department. There are 4 production lines in the production department of the electric refrigerator. The company can consider making the production line rotation plan, so that the work content of the monitor is no longer restricted to single product production, so that the work is enriched. Inspection, supervision and production of different products will keep class leaders fresh and have a sense of achievement for different products. At the same time, they are also good for monitor to familiar with different production processes and be helpful for their own development.

\section{Give the Monitor More Substantive Power}

Monitor play the role of upload issued in the company, reporting to the superior line of work, supervision of staff down production, is responsible for assist daily production management, there is no substantive power, it will make monitor who as first-line managers sense and the sense of participation does not exist in the organization. Monitor and employee contact is the most, the most easy to find and potential problems have emerged in the production. Therefore the line and monitor the meeting held between, held between the cable length and body length of length superior business meeting, the meeting held between the length and operating body length, body length on the operation of small and micro level the LORD shall properly arrange a certain proportion of monitor in the important issue of the decision can listen to monitor's reasonable opinions .Secondly, a leader with a long line or even a long line can release the task as fast as possible in the process of releasing tasks. Instead of meeting new problems, the monitor must ask the superior or ask the superior to inform the monitor so that the monitor feels constrained. Finally, giving the monitor certain power within a reasonable scope and decentralization, is helpful for the monitor's daily production management and the establishment of authority in the front-line staff.

\section{Incentives Based on Relationship Needs}

Organize rich collective activities. Wuhan Haier can divide the monitor into a number of groups and organize team building activities regularly. By gathering together to work and communicate in order to discover and improve the problems in the production line. In the course of the whole process, monitors will be more aware of each other, enhance trust, and be beneficial to the maximization of the company's output. In addition, employees in the Organization questionnaire expressed the hope that company can organize more leisure activities. Meanwhile, their supervisors' satisfaction with the relationship between the subordinates and their colleagues is relatively low, and the incentive level of interpersonal relationship is also important. Therefore, the company can organize amateur activities regularly, so that employees can enhance their feelings in a relaxed and pleasant atmosphere, temporarily forget the operation and the same process of production line, create a harmonious atmosphere and enhance the relationship between monitor and subordinates .Finally, the superiors should also recognize the work of the monitor more often, and give more condolences to the monitor. At the same time, the monitor should also give more recognition to the front-line employees, so that employees can feel the concern from the company and the superiors and enhance the cohesion of Wuhan Haier.

\section{Conclusion and Prospect}

This study analyzes the problem of the motivation of the Wuhan Haier Monitor and gives the 
corresponding countermeasures, in addition to the specific suggestions above, we should also pay attention to the following points: first, pay attention to the transformation between health care factors and incentive factors. For example, income and housing are survival needs, according to the Herzberg double factor theory, they should be included in the health factors, but, under the influence of China's national conditions, in Wuhan Haier, for the monitor, both are incentive factors. Second, the company in addition to the use of external material incentives, internal spiritual incentives can not be ignored, and even the intrinsic spiritual motivation will play a greater role. Third, in order to maximize the incentive effect, the company should use a variety of incentive methods.

There are many deficiencies in this study. First of all, the relevant content of the questionnaire is the author based on the Oldever "ERG Need Theory" and Hertz's "dual-factor needs theory" of their own adaptation, may not be scientific rigorous. Secondly, the field investigation and distribution of questionnaires, may affect the normal work of the monitor and monitor the information leakage, do not exclude the possibility of the survey data distortion. Finally, the data analysis and processing of this study has further research space.

\section{References}

[1] Meng Jun. The study of employee motivation in the Internet era: a kind of intrinsic incentive mode relying on cultural maintenance--take Alibaba Group as an example [J]. China human Resources Development, 2016 (16): 16 22 (in Chinese)

[2] David O.Ulrich, Bonnie L. Parkhouse. The Application of Motivation Theory in Management to the Sport Arena[J].Quest,1979,31(2): 302 311

[3] Leonard.NH, Beauvais.LL, Scholl.RW. Work Motivation: The Incorporation of Self-Concept-Based Processes[J]. Human Relations,1999,52(8):969 998

[4] Khalil Ghazzawi, Pierre Al-Khoury, Judy Saman. The Effect of Implementing Technology in HRM on the Level of Employee Motivation[J].Human Resource Management Research,2014,4(2): 33 39

[5] Li Mo. Motivational psychology analysis of motivation theory [J]. Business Economics Research, 2008 (35): 51 51 (in Chinese)

[6] Flippo(1984), Personnel Management sixth edition (New York: McGraw Hill BookCo,1984),p.392

[7] Groebner, David, and Shannon, Patrick. Business Statistics (1981): A Decision-Ma king Approach. Columbus: Charles Merrill Publishing Company

[8] Ma jie. On perfecting the incentive mechanism of enterprise employees [J]. SME management and Technology (mid-Journal), 2015 (11): 7 8 (in Chinese) 